\title{
Dokumentacja masowa
}

\section{- PROBLEMY WARTOŚCIOWANIA I SELEKCJI}

$\mathbb{W}$ dniach 25 i 26 listopada 2010 r. w Instytucie Historii UAM odbyła się konferencja naukowa poruszająca problematykę wartościowania dokumentacji masowej. Jej organizatorami były NDAP, Zakład Archiwistyki Instytutu Historii UAM w Poznaniu, SAP oraz AP w Poznaniu.

W konferencji wzięło udział około 100 osób. Wśród zebranych nie zabrakło przedstawicieli instytucji sektora państwowego, placówek naukowych, studentów oraz zainteresowanych tematyką wartościowania dokumentacji masowej.

Obrady rozpoczęły się 25 listopada 2010 r. o godz. 10. Stanisław Sierpowski przywitał zebranych gości, przedstawiając członków prezydium obrad, w tym zastępcę Naczelnego Dyrektora Archiwów Państwowych Andrzeja Biernata jako przewodniczącego, Irenę Mamczak-Gadkowską, Krzysztofa Stryjkowskiego. Gościem specjalnym tej części obrad była dziekan WNH Hanna Kóčka-Krenz.

Jako pierwsza wystąpiła Ewa Perłakowska (NDAP), wygłaszając referat zatytułowany „Wartościowanie dokumentacji masowej - zdefiniowanie problemu". Autorka podjęła się próby zdefiniowania problemu dokumentacji masowej i masowości akt, podkreślając jednocześnie, że stosowanie tych pojęć zamiennie jest niewłaściwe, a samo ich określenie nie jest łatwe. Referentka zwróciła uwagę na zjawisko masowości akt i jako przykłady podała księgi wieczyste, dokumentację medyczną, dokumentację dotyczącą kolczykowania zwierząt, terenów rolnych, akta studenckie, sądowe, USC, komisji egzaminacyjnych itp. Pozwoliło to na postawienie tezy, iż poza ilością, cechą wspólną tej dokumentacji jest jej jednolitość. Jako rozwiązanie problemu masowości akt prelegentka zaproponowała metodę statystyczną, przedstawiając przykład dokumentacji szkolnej dużego i małego miasta - w większym mieście wybierze się dokumentację trzech wybranych szkół, a w mniejszej miejscowości niewykluczone, że zachowa się całość.

Nieobecną Halinę Robótkę (UMK) zastąpiła Katarzyna Pepłowska, odczytując referat zatytułowany „Wartościowanie akt. Teraźniejszość i przyszłość". Autorka referatu dokonała podsumowania osiągnięć długiego okresu kształtowania się metod, procedur oraz narzędzi wartościowania akt, przypadającego na XIX i początek XX w. Jak słusznie zauważyła, dyskusja nad se- 
lekcją, obecna od połowy lat dziewięćdziesiątych XX w., powraca do korzeni, do teorii H. Jenkinsona i T. Schellenberga. H. Robótka zwróciła szczególną uwagę na „makroselekcję”, którą należy rozumieć jako ogólne cele wartościowania uwzględniające szeroki kontekst występowania i wytwarzania dokumentacji bądź też teorię wartościowania, nowe rozwiązania praktyczne, do których włącza się metodologię i kryteria. Za przykłady państw realizujących założenia „makroselekcji” autorce posłużyły Kanada i Holandia. Podsumowując swoje wystąpienie, autorka nie omieszkała wystosować postulatu, że konieczna jest modyfikacja stosowanych praktyk wartościowania, a zaproponowana przez nią makroocena/makroselekcja preferuje powrót do korzeni, do praktyk stosowanych w XIX w., gdy urzędnicy przy wsparciu archiwistów wybierali cenną dokumentację.

Prawnymi aspektami selekcji zajął się Marek Konstankiewicz (UMCS), który zaprezentował zestawienie aktów prawnych dotyczących selekcji. Swoje wystąpienie zatytułowane „Podstawy prawne archiwalnej selekcji dokumentacji” referent rozpoczął od omówienia ustawy archiwalnej łącznie ze zmianami, jakie zaczną obowiązywać od 2011 r. Następnie omówił szereg przepisów szczegółowych rozproszonych w licznych normatywach, w których możemy odnaleźć regulacje dotyczące sposobu postępowania z dokumentacją. Referent pod koniec swojego wystąpienia zwrócił uwagę na autonomię wytwórców niepaństwowego zasobu archiwalnego w kwestii selekcji dokumentacji.

$\mathrm{Z}$ nieco innej perspektywy problem selekcji dokumentacji masowej przedstawił Rafał Galuba (UAM) w wystąpieniu zatytułowanym „Problemy wartościowania i selekcji dokumentacji w archiwach wyodrębnionych”. Na wstępie referent dokonał podziału archiwów wyodrębnionych na archiwa konstytucyjnych organów władzy i administracji rządowej, organów bezpieczeństwa i ochrony oraz IPN, po czym przypomniał najważniejsze akty prawne regulujące kwestie związane z funkcjonowaniem archiwów wyodrębnionych, tj. konstytucję, ustawę o dostępie do informacji publicznej, ustawę o prokuraturze, rozporządzenie dotyczące nadawania klauzul tajności, ustawę o ochronie informacji niejawnych, rozporządzenie dotyczące postępowania sprawdzającego, ustawę o działalności ABW i SKW oraz ustawę o ochronie baz danych. Ponadto zwrócił uwagę na stosowane kryteria wartościowania dokumentacji, wśród których wyróżnił kryterium polityczne jako najważniejsze.

Autor stwierdził, że archiwa wyodrębnione zostały wyłączone spod nadzoru obywatelskiego pomimo obywatelskiego prawa do dostępu do informacji publicznej - informacje przechowywane w archiwach wyodrębnionych nie są niczym innym jak informacją publiczną w rozumieniu właściwej ustawy. Mówiąc o paradoksach, prelegent zwrócił uwagę na problem „wiecznego” sta- 


\section{KRONIKA}

tusu dokumentacji niejawnej, który z punktu widzenia praw obywatelskich może być ich naruszeniem. Ponadto zaakcentował problem bezprawnego brakowania dokumentacji zawierającej tajemnice prawnie chronione.

Eugeniusz Borodij (AP w Bydgoszczy) w wystąpieniu zatytułowanym „Dokumentacja masowa w wykazach akt” zdefiniował dokumentację masową jako dokumentację o sformalizowanym sposobie produkcji i określonym formularzu, zapisywaną na nośnikach tradycyjnych, jak i cyfrowych, niezawierającą jednak informacji syntetycznych. Zauważył, że dokumentacja ta stanowi: „przerażającą część produkcji dokumentacji w danej instytucji”. Referent zwrócił uwagę słuchaczy na masowość formularzy, które różnią się wyłącznie zawartością danych osobowych, skrytykował stosowaną praktykę nadawania kwalifikacji archiwalnej dokumentacji medycznej przez lekarzy oraz poddał pod refleksję słuchaczy użyteczność i celowość przechowywania wyżej wymienionej dokumentacji dla przyszłych badaczy.

Wystąpienie E. Borodija wywołało dyskusję wśród zebranych. Przede wszystkim uczestników spotkania zainteresował problem masowości dokumentacji osobowej i płacowej. Przedstawicielka Kancelarii Sejmu Grażyna Kubicka zwróciła uwagę na personel, który nie jest merytorycznie przygotowany do pracy z dokumentacją masową, twierdząc, że pracownicy kancelarii nie są w stanie odróżnić pisma przewodniego od pozostałej dokumentacji dotyczącej konkretnej sprawy. Ten sam problem zauważyła Wiesława Kwiatkowska, mówiąc o potrzebie wypracowania skutecznych metod kształcenia archiwistów. Ponadto głos zabrała przedstawicielka kancelarii NIK - odnosząc się do podejmowanych zagadnień, omówiła organizację kancelarii, do której prawidłowego funkcjonowania niezbędne są uregulowania dotyczące postępowania z dokumentacją masową.

Dyskusja toczyła się burzliwie. Ścierały się głosy praktyków i teoretyków, ujawniające wiele niedociągnięć ze strony praktycznego zarządzania dokumentacją masową. $\mathrm{Z}$ naukowego punktu widzenia ponowił się postulat pilnej potrzeby uregulowania tego problemu, który - jak to było widoczne podczas dyskusji - narasta.

Po dłuższej przerwie rozpoczęła się druga część obrad, której przewodniczyła Alicja Kulecka, a w skład prezydium obrad weszli E. Perłakowska i K. Stryjkowski. Otwierający tę część konferencji referat Joanny Louchin (AP Dokumentacji Osobowej i Płacowej) pt. „Masowość dokumentacji personalnej oraz jej wartościowanie na przykładzie zasobu Archiwum Dokumentacji Osobowej i Płacowej” był kontynuacją rozważań podjętych podczas dyskusji. Referentka zwróciła uwagę na wartość historyczną akt osobowych, których zasób w APDOiP sięga około 12000 m.b., oraz cenny zbiór fotogra- 
fii, których liczba sięga około $46 \mathrm{mln}$. Te fotografie pochodzą nie tylko z akt osobowych, ale również z metryczek (wtórników przy wypełnianiu wniosku o wydanie dowodu osobistego), których zbiór sięga około 22000 m.b. akt. Świadectwem znaczenia tego typu dokumentacji mogą być teczki osobowe pracowników przejęte z zakładów „Ursus”, stanowiące - z uwagi na znaczenie zakładu dla najnowszej historii Polski - cenny materiał badawczy.

Kolejny referat autorstwa Leszka Wilczyńskiego, zatytułowany „Dokumentacja masowa w kancelariach parafialnych i archiwach kościelnych”, był potwierdzeniem przyjętej na wstępie tezy autora, że masowość akt zalewa również organizacje kościelne. Referent przywołał zapisy prawa kanonicznego, które wyraźnie stanowi, że dokumentacji kościelnej powstałej przed 1900 r. nie brakujemy. L. Wilczyński podkreślił znaczenie szeroko rozumianej działalności dokumentacyjnej prowadzonej przez kancelarie parafialne i archiwa kościelne. Jej wynikiem jest dokumentacja odzwierciedlająca całokształt aktywności Kościoła.

Po krótkiej przerwie przedstawiono dwa referaty, omawiające zasady postępowania z dokumentacją masową w przeszłości. Stefan Ciara (UW) w referacie zatytułowanym „Doświadczenia archiwistów galicyjskich na przełomie XIX i XX w. w zakresie postępowania z dokumentacją masową”, opierając się przede wszystkim na doświadczeniach dziwiętnastowiecznych archiwistów, omówił kwestie postępowania z dokumentacją masową, kładąc nacisk na dokumentację sądową.

W drugim referacie autorstwa Adama Dąbrowskiego (AAN) poruszono problem „Wartościowania i selekcji akt centrali Ministerstwa Spraw Wewnętrznych i podległych mu urzędów administracji ogólnej oraz Policji Państwowej w świetle przepisów o przechowywaniu akt z lat 1931-1939”. Referent przedstawił przepisy prawne obowiązujące w interesującym go okresie, omówił typową dokumentację wytwarzaną przez MSW, policję oraz podległe im jednostki, zwracając uwagę na sposób brakowania tej dokumentacji. To wystąpienie zakończyło odczyty referatów pierwszego dnia konferencji.

Dyskusja kończąca pierwszy dzień obrad była niewątpliwie kontynuacją wcześniejszej i dotyczyła problemów związanych z dokumentacją osobową, płacową i medyczną. E. Borodij, jako pierwszy jej uczestnik, poddał pod dyskusję pogląd dotyczący ochrony tajemnicy lekarskiej. Stwierdził, że obywatele polscy cenią sobie pewną intymność informacji dotyczących ich stanu zdrowia. Na sali nie zabrakło przeciwników owej opinii. W. Kwiatkowska uznała, że dokumentacja medyczna jest cennym źródłem do badań, a informacje w niej zawarte nie powinny godzić w intymność osób w 200 lat po ich śmierci. Nieco inny pogląd w tej sprawie zaprezentowała E. Perłakowska, 
która radziła, aby dokumentację medyczną podzielić na dwie grupy. Pierwszą dotyczącą okresowych badań, drugą zaś diagnostyczną. Jak słusznie stwierdziła, dokumentacja medyczna dotycząca diagnostyki ma większe znaczenie z punktu widzenia jej przydatności. Dlatego też zdaniem E. Perłakowskiej tę dokumentację powinniśmy zachowywać.

Drugi wątek poruszony w dyskusji odnosił się do dokumentacji osobowej. Rozmowy toczyły się pomiędzy J. Louchin, która postulowała zachowanie tej dokumentacji jako istotnego źródła informacji, E. Perłakowską, twierdzącą, że nie możemy zachować wszystkiego, Maciejem Jasińskim (Archiwum Urzędu m.st. Warszawy), który podczas pracy spotkał się z dużym zainteresowaniem ową dokumentacją, oraz Henrykiem Krystkiem (AP w Poznaniu), który zwrócił z kolei uwagę na finansowe aspekty zachowywania dokumentacji osobowej. Głos w tej sprawie zabrała również Hanna Staszewska (AP w Poznaniu), postulując, by kwestie selekcji były regulowane przez badania nad potrzebami informacyjnymi przyszłych pokoleń. Jako przykład wskazała dokonania bibliotekarzy, którzy przez prowadzenie badań statystycznych są w stanie zaplanować, jakie materiały będą poszukiwane w przyszłości.

Drugi dzień konferencji rozpoczął się o godzinie 9 przywitaniem uczestników. Na przewodniczącego obrad wyznaczono Waldemara Chorążyczewskiego (UMK).

Roland Banduch (AP w Katowicach) wygłosił referat zatytułowany „Dokumentacja techniczna, jej masowość i problemy wartościowania”. Zwrócił on uwagę na specyfikę dokumentacji technicznej, która zostaje wytworzona i jest przechowywana w kilku egzemplarzach - w biurze projektowym, u inwestora, u właściciela obiektu bądź w_odpowiednim urzędzie, co powoduje nagromadzenie dokumentacji o jednōitej treści. Zdaniem referenta generuje to problem powielającej się dokumentacji, do której ogólne kryteria wartościowania nie zawsze mają zastosowanie.

Kolejne dwa wystąpienia zostały poświęcone rozwiązaniom problemu masowości akt w krajach zachodnich. Joanna Chojecka (AP w Koszalinie) w referacie zatytułowanym „Problem wartościowania dokumentacji masowej w Niemczech", omawiając akty prawne regulujące funkcjonowanie archiwów, zaprezentowała poglądy archiwistów niemieckich. Najwięcej uwagi referentka poświęciła praktyce wartościowania - samplingowi, który w przypadku Niemiec ma zastosowanie w odniesieniu do akt m.in. osobowych czy też socjalnych. Podstawową zasadą wyboru grupy reprezentacyjnej jest zasada pierwszej litery nazwiska, górująca nad metodą statystyczną czy też chronologiczną, praktykowaną w Bawarii. „Problem wartościowania dokumentacji masowej w krajach frankofońskich” przedstawił K. Stryjkowski (UAM), któ- 
ry nie omieszkał pominąć poglądów Międzynarodowej Rady Archiwów na temat dokumentacji masowej, począwszy od 1956 r. do lat obecnych, przytaczając jednocześnie stanowisko MRA z 1956 r., jasno mówiące, że archiwa nie mają uprawnień do walki z dokumentacją masową. Jak zaznaczył, problem dokumentacji masowej jest obecnie przedmiotem zainteresowania społeczności międzynarodowej. Referent zwrócił uwagę na etapy selekcji oraz jej metody w krajach frankofońskich. Omawiając dokumentację masową, do której zaliczamy nie tylko dokumentację pracowniczą czy medyczną, ale również dokumentację rachunkową, techniczną, sądową, wyborczą, szkolną, socjalną, akademicką, zaznaczył, że problem masowo powstającej dokumentacji musi zostać pilnie rozwiązany z uwagi na problemy logistyczne, interes badawczy oraz koszty z tym związane.

Wystąpienie Iwony Fischer (AP w Krakowie) podkreślało rolę użytkowników archiwów, którzy zdaniem autorki mają najwięcej do powiedzenia w tej kwestii. W referacie zatytułowanym „Konsekwencje wartościowania i selekcji dokumentacji masowej dla użytkowników archiwów" poddała ona pod refleksję ich zapotrzebowania. Zwróciła uwagę na fakt, że użytkownik XXI w. coraz częściej jest zainteresowany dokumentacją masową, de facto zaliczaną do dokumentacji merytorycznej. Dlatego też archiwiści nie powinni podcinać gałęzi badaczom, którzy właśnie w dokumentacji masowej upatrują podstawy badawczej swoich zainteresowań. W wystąpieniu I. Fischer nie zabrakło słów krytyki pod adresem archiwistów, brakujących dokumentację ze względu na brak miejsca do jej przechowywania.

W referacie zatytułowanym „Dokumentacja masowa w badaniach historycznych” A. Kulecka (UW) podniosła problem terminologiczny, zastanawiając się, czym jest dokumentacja masowa. Jak sama stwierdziła, to pojęcie nie istnieje w języku historiografii. Jedynym terminem, z którym historyk styka się w trakcie swoich badań, są „źródła masowe”, a z ich krytyką wiążą się odrębne procedury badawcze. Zdaniem referentki źródła masowe powstają w wyniku zwiększonej działalności państwa, które chce ingerować we wszystkie sfery życia człowieka, a wykorzystuje się je chociażby do badania gospodarki, historii rozwoju, dziejów zbiorowości, historii społecznej czy też architektury.

Po wszystkich wystąpieniach przewodniczący obrad otworzył dyskusję. Jako pierwszy głos zabrał M. Jasiński, odwołując się do referatu K. Stryjkowskiego. Wspominając Kongres MRA w Kuala Lumpur i kwestie dotyczące przechowywania dokumentacji w Japonii i Chinach, stwierdził, że tam zachowuje się każdą informację o przodkach, co wiąże się z głęboko zakorzenioną tradycją. Zauważył, że lepiej pozostawić o jeden metr bieżący akt więcej, niż wybrakować jeden ważny dokument. Jako druga głos zabrała J. Louchin. 
Zwróciła uwagę na specyfikę polskiego zasobu, porównując go z zasobem państw zachodnich. Niekompletny zasób polskich archiwów skutkuje niezadowoleniem użytkowników. Postulowała również, by archiwiści poważniej podchodzili do swoich obowiązków, jeżeli chcą siebie nazywać „kustoszami pamięci”. K. Stryjkowski przypomniał zebranym, że problem masowości akt jest problemem na skalę międzynarodową, z którym każde państwo boryka się na swój własny sposób. Przywołał tutaj pogląd E. Borodija odnoszący się do „intymności”, którego nie powinniśmy lekceważyć. Dyskutant w swojej wypowiedzi nie omieszkał ominąć wystąpienia I. Fischer, zarzucając jej „archiwopaństwocentryzm". Z nieco innej perspektywy swoje refleksje zaprezentował S. Sierpowski. Wyraził niepokój, że dzisiejszy archiwista nie podchodzi emocjonalnie do zawartości archiwum, a przecież archiwiści powinni prowadzić działalność naukową, bo kto inny, jak nie archiwista, powinien podejmować badania choćby z zakresu regionalistyki. Drugą kwestię, którą poruszył, była masowość powstającej dokumentacji, której nie da się opracować, a przez to staje się ona bezużyteczna w badaniach naukowych. A. Dąbrowski (AAN) nawiązał do referatu I. Fischer, mówiąc, że sędzia nie jest historykiem, dlatego też sędzia, jako główny podmiot dokumentacji sądowej, nie może decydować, co powinniśmy zachować dla potomnych, a co zniszczyć. Dlatego też archiwiści muszą wykazać się czynnym działaniem przy wartościowaniu - powinni pomagać archiwistom zakładowym w wartościowaniu ich akt, ponieważ ci nie zawsze posiadają wiedzę, pozwalającą ocenić wartość historyczną akt. W. Kwiatkowska, przysłuchując się dyskusji, wyraziła zaniepokojenie, że w oczach historyków ciekawym materiałem badawczym są jedynie archiwalia do 1950 r. Dlatego też, jej zdaniem, archiwiści powinni ostrożnie podchodzić do brakowania akt najnowszych, zwracając uwagę na obecne kierunki badań, które oscylują wokół życia codziennego człowieka, a użytkownicy poszukują akt jednostkowych. H. Krystek dodał, że to właśnie archiwa państwowe będą zobowiązane do wyjaśnienia kwestii związanych z postępowaniem z dokumentacją masową, ponieważ to one kontrolują powstawanie dokumentacji na podległym terenie, a problemy dopiero się pojawią. Z pewnością stworzy je upowszechnienie w archiwach dokumentów w formie elektronicznej. To zjawisko będzie połączone z pilną potrzebą wypracowania niezbędnych narzędzi do zarządzania nimi. Wygeneruje to kolejne problemy legislacyjne, magazynowe czy też finansowe. Grażyna Kubicka zauważyła, że postępowanie z dokumentacją masową w praktyce przysparza wielu problemów i pytań. Ponadto są ograniczenia dostępu do tego typu dokumentacji. Czy można dziennikarzowi udostępnić materiały z biura poselskiego? Czy zeznania podatkowe należy brakować po pięciu latach? W jaki 
sposób archiwizować strony internetowe? Wyżej wymienione pytanie dyskutantka pozostawiła bez odpowiedzi, twierdząc jednocześnie, że komputeryzacja współczesnych instytucji w połączeniu z masowością dokumentów w formie elektronicznej sparaliżuje prace kancelarii oraz archiwum zakładowego. Jako ostatni głos zabrał L. Wilczyński. Przypomniał, że Kościół rzymskokatolicki zachowuje całą wytwarzaną dokumentację. Zasugerował, aby także inni twórcy rozważyli to rozwiązanie, dzięki czemu problemy, o których mówiono w trakcie dyskusji, zyskałyby zupełnie inny wymiar.

Syntetycznego podsumowania konferencji dokonała A. Kulecka. Podziękowała referentom. Stwierdziła, że powinniśmy zastanowić się nad zasadnością naszych rozważań. Zagadnienia wartościowania dokumentacji masowej wiążą się z jasno określoną terminologią, jasno postawionymi celami oraz środkami do ich osiągnięcia. W tym wszystkim nie możemy pominąć użytkowników - ich oczekiwania badawcze zmieniają się bowiem w szybkim tempie postępu cywilizacyjnego, któremu archiwa muszą sprostać. Dlatego też teza I. Fischer, że dokumentacja masowa jest przedmiotem zainteresowania użytkowników, burzy twierdzenie archiwistów o jej przydatności.

Marta Pawtowska, Katarzyna Peptowska (Uniwersytet Mikołaja Kopernika w Toruniu)

\section{Panel Sekcji Edukacji Archiwalnej SAP DOTYCZĄCY PODRĘCZNIKÓW DO NAUKI ARCHIWISTYKI}

D) nia 26 listopada 2010 r., w czasie zorganizowanej w Poznaniu konferencji poświęconej problemom wartościowania dokumentacji, odbył się panel Sekcji Edukacji Archiwalnej Stowarzyszenia Archiwistów Polskich. Jego tematem przewodnim były podręczniki do nauczania archiwistyki. W spotkaniu uczestniczyli członkowie zarządu sekcji: Wiesława Kwiatkowska, Irena Mamczak-Gadkowska (UAM), Leszek Wilczyński, Waldemar Chorążyczewski (UMK), Lucyna Harc (UWr), Agnieszka Rosa (UMK), oraz goście: Alicja Kulecka, Stefan Ciara (UW), Krzysztof Stryjkowski, Barbara Kalinowska-Wójcik (UŚl).

Odczytano sześć referatów. Jako pierwszy głos zabrał Hubert Wajs (AGAD), omawiając rolę podręcznika MAD 3 (Manual Archival Description), wykorzystywanego w Wielkiej Brytanii. Drugim interesującym go 